\title{
Dee regulation reservoirs
}

John Hopkins BSc(Hons), CEng, FICE

Technical Director, Black \& Veatch, Redhill, UK (corresponding author:

hopkinsj@bv.com)

The management of water resources on the River Dee represents a major example of advanced river basin management. It combines the supply of water, flood alleviation, fishery management, recreation and hydro-power generation. Three reservoirs, Llyn Tegid, Llyn Celyn and Llyn Brenig assist in managing flows in the River Dee. A fourth, Alwen Reservoir, supplies water directly by pipeline. The history, reservoir development and operation of the Dee Regulation scheme are discussed.

\section{Introduction}

The River Dee (Afon Dyfrdwy) rises in the Snowdonia National Park, to the west of Bala Lake (Llyn Tegid). It then flows east through the Vale of Llangollen before meandering northwards towards the Cheshire plain to its tidal limit at Chester Weir. The management of water resources on the River Dee represents a major example of advanced river basin management. It combines the supply of water, flood alleviation, fishery management, recreation and hydro-power generation. Three reservoirs, Llyn Tegid, Llyn Celyn and Llyn Brenig assist in managing flows in the River Dee (Figure 1). A fourth, Alwen Reservoir, supplies water directly by pipeline.

\section{The Dee regulation scheme}

The natural flow of the River Dee, during dry summer weather, would be insufficient to sustain any significant abstractions; but if excess flood flows can be stored in reservoirs, this water may be released later in dry weather to supplement the low natural river flows, permitting continuous abstractions from the river. This is the principle of low-flow regulation and was used by Telford at the beginning of the nineteenth century. In order to guarantee a supply of water to the Ellesmere Canal (now part of Shropshire Union Canal), which commences at the Horseshoe Falls, near Llangollen, Telford constructed sluices at the outlet of Bala Lake.

The rise in demand for water generated by the Industrial Revolution, and the public health issues of polluted rivers and other traditional local sources near cities, resulted in the construction of numerous reservoirs in natural valleys during the latter half of the nineteenth century based on the 'direct supply' principle, with the relatively clean upland reservoir water being subjected to basic treatment processes before being piped away to the area of supply. The only substantial directsupply reservoir constructed in the Dee catchment was Alwen Reservoir, which was originally intended to supply Birkenhead.

In the 1950s, the Dee and Clwyd River Board promoted and constructed the Bala Lake Scheme. The scheme was originally conceived before the Second World War as a means of reducing flooding in the Dee valley. The revised scheme was constructed between 1953 and 1956 to achieve two main purposes; reducing flooding, and providing additional water for river support during low flow periods, thereby increasing the amount of water available for abstraction by the various water undertakings. In parallel with this development, more stringent standards were imposed on those effluents which discharged into the Dee upstream of Chester. Over 150 years after Telford's original scheme, the principle of river regulation had been re-established on the River Dee.

Many rivers in industrial areas became too polluted by effluents to be usable for water supply, and the relatively small amounts of 'compensation water' discharged to the rivers by the direct-supply reservoirs were insufficient to redress the situation. However, the City of Chester provided a notable exception to this generality, having directly abstracted Dee water since the first Chester Waterworks Company was formed in 1826. This was possible due to the relatively few troublesome effluents in the Dee catchment upstream of Chester.

The success of the Bala Lake scheme after its completion in 1956 strengthened the growing interest in multi-purpose management of the River Dee. A proposal by the Corporation of Liverpool for a supply to be discharged into the River Dee from an impounding reservoir on the Tryweryn tributary and abstracted for treatment at Huntington, 80 river miles downstream near Chester, was changed to a river regulation scheme for the mutual benefit to Liverpool, the River Board and other abstractors. Powers were obtained by Act of Parliament in 1957 and the reservoir built on the Afon Tryweryn (Llyn Celyn) has been used jointly with Bala Lake to regulate the River Dee since 1965.

The Dee and Clwyd River Authority Act 1973 established a unique statutory framework for the operation of Llyn Tegid, Llyn Celyn and Llyn Brenig to regulate the River Dee; carried out by the River Authority with the assistance of the Dee Consultative Committee, representatives of major abstractors from the River Dee. With reorganisation of the water industry 


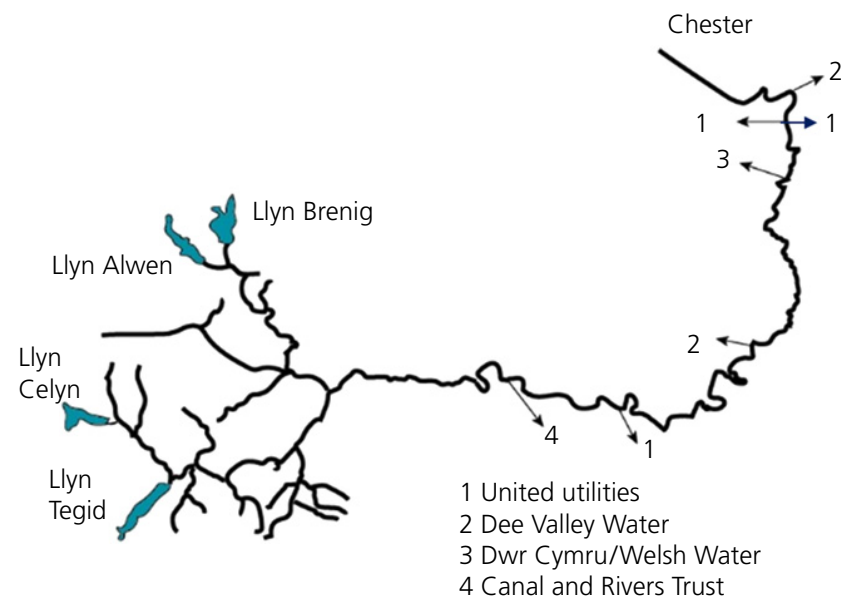

Figure 1. The River Dee - A Regulated River

in 1974, responsibility for the Brenig scheme and Dee regulation passed to the Welsh National Water Development Authority.

In 1989, following the privatisation of the water industry, the regulation of the River Dee came under the control of the National Rivers Authority, which was succeeded by Environment Agency Wales in 1996. In 2013 the management of flows came under the joint control of Natural Resources Wales and the Environment Agency.

In 2018 the authorised abstractions by the three statutory undertakings and the Canal and River Trust were:

$\begin{array}{lc}\text { United utilities } & 666 \cdot 4 \mathrm{Ml} / \mathrm{d} \\ \text { Dee Valley Water } & 78.0 \mathrm{Ml} / \mathrm{d} \\ \text { Canal and Rivers Trust } & 28.3 \mathrm{Ml} / \mathrm{d} \\ \text { Dwr Cymru Welsh Water } & 34 \mathrm{Ml} / \mathrm{d}\end{array}$

In addition, a residual flow of at least $364 \mathrm{Ml} / \mathrm{d}$ is maintained over Chester Weir, in all but the most extreme droughts. This safeguards migratory fish and limits the amount of saline water over Chester Weir during high tides.

\subsection{Impact of low flow and flood control on Bala Lake levels}

In the period before 1955, prior to the commissioning of the Bala Lake Scheme, control was by means of Telford's sluice and flooding was a major issue for the town of Bala and other areas of low-lying land downstream. From 1956 to 1964, after commissioning of the Bala scheme but before the introduction of Llyn Celyn, high lake levels reduced through the lowering of the lake outlet channel and sill. This period though had variability with a tendency for higher water levels associated with the additional water from the Tryweryn catchment flowing into Bala Lake. High lake levels reduced further after 1965 when Celyn became operational and flood storage on the Tryweryn catchment reduced runoff. Since 1974 the scheme has been operated with 'summer bandwidth' control.

\subsection{Operation of the regulation scheme}

The scheme is operated to set a fair balance between the many interests and without undue constraints from any particular groups of users. The Dee and Clwyd River Authority Act 1973 re-constituted a consultative committee on which both major abstractors and river interests are representative. This committee was first established under the 1951 Dee and Clwyd River Board Act and re-constituted under the 1957 Act of Parliament. The complex rules used to operate the system, are prepared with the Committee's advice, and the operation in severe droughts require the Committee's approval.

During the summer months, Bala Lake is operated within a $0 \cdot 4 \mathrm{~m}$ bandwidth between $160 \cdot 3$ and $160 \cdot 7 \mathrm{~m}$ OD (Figure 2).

Llyn Celyn is operated to a set of control curves including a $3 \mathrm{~m}$ bandwidth for flood storage during the winter months (Figure 3).

During the summer months when river flows are supported by discharges from Llyn Celyn and Llyn Brenig, the release from Celyn is initially transferred to Bala Lake, prior to regulated releases through the sluice gates and on down the River Dee. This ensures that Bala Lake is maintained within its operational bandwidth at times of low natural flows.

\section{Bala Lake (Llyn Tegid)}

Bala Lake is a natural glacial lake, $6 \mathrm{~km}$ long, $800 \mathrm{~m}$ wide with a surface area of $4 \cdot 8 \mathrm{~km}^{2}$ and a maximum depth of $42 \mathrm{~m}$.

\subsection{Sluice for Ellesmere Canal}

Sluice gates were built just downstream of the outlet from Bala Lake for the Ellesmere Canal c.1804 as part of the water control scheme designed by William Jessop and Thomas Telford. They were designed to raise the level of Bala Lake in summer by one foot, ensuring that the canal would be constantly fed with water by way of the River Dee and the feeder canal starting at Llantysilio Weir (Horseshoe Falls). Later problems with flooding led to the sluice gates being lowered in 1808. The sluice gates were bypassed and part demolished as part of the Bala Lake Scheme implemented by the Dee and Clwyd River Board in the 1950s.

\subsection{The Bala Lake Scheme}

The Bala Lake Scheme involved lowering the natural lake outlet with new sluice gates constructed downstream of the 


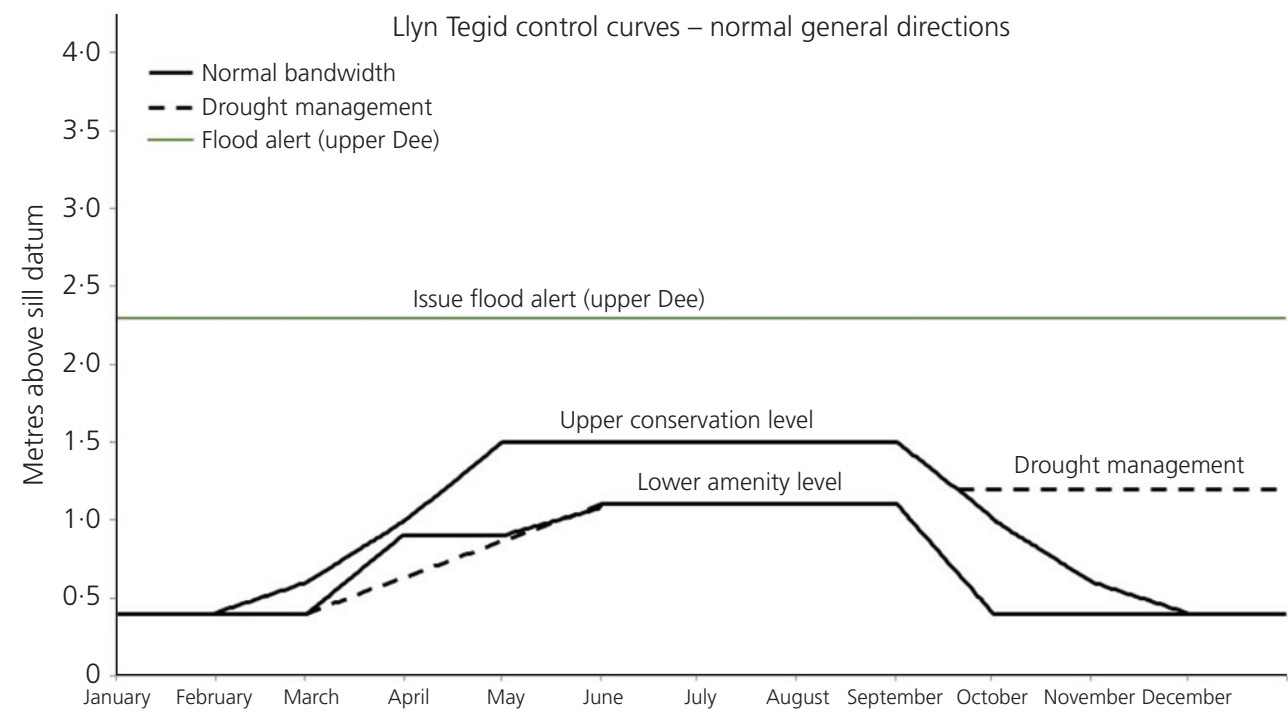

Figure 2. Llyn Tegid Control Curves

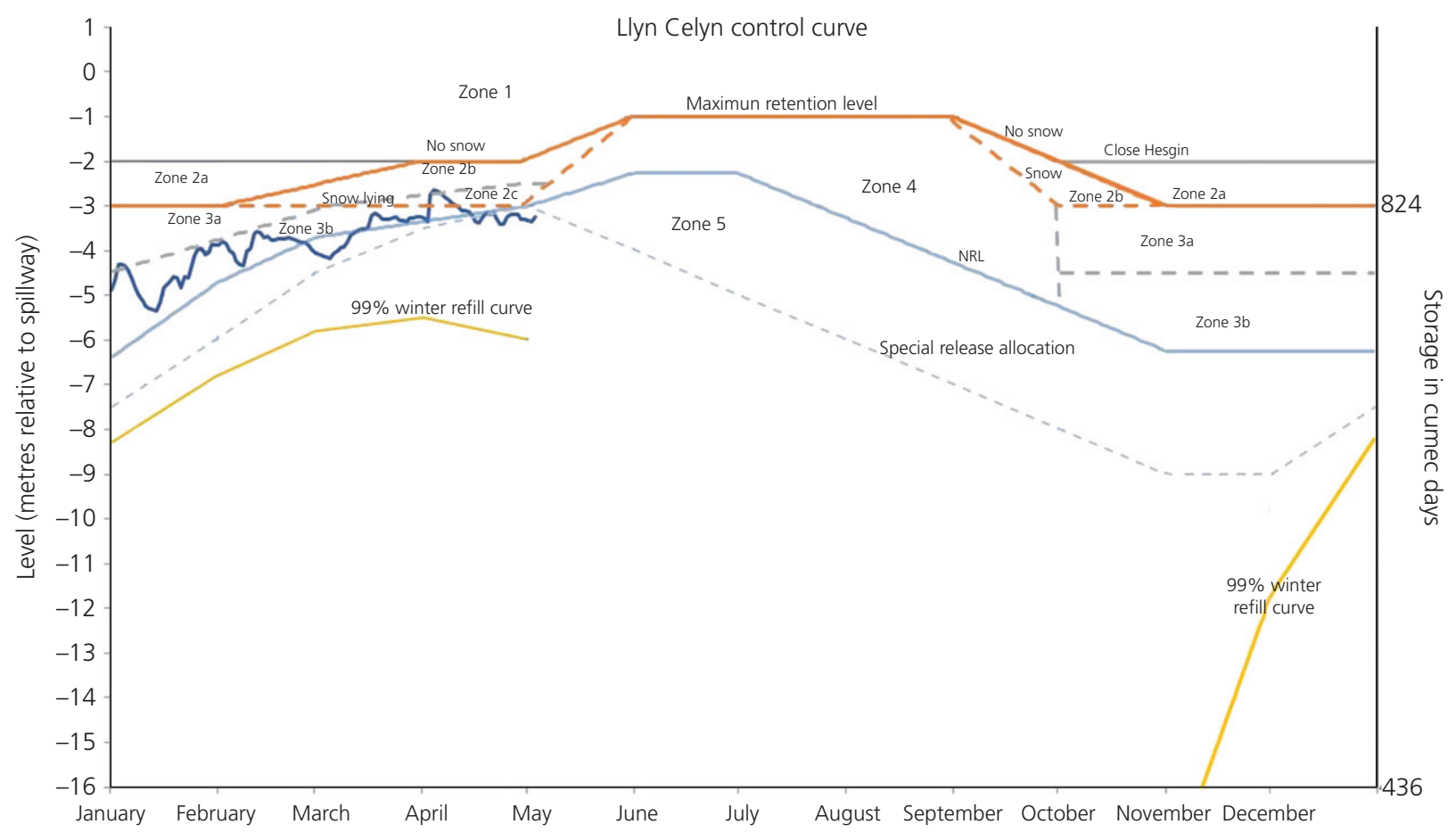

Figure 3. Llyn Celyn Control Curves

confluence with the Afon Tryweryn, a short distance from the lake outlet (Figures 4 and 5). The new sluice sill was set at $159 \cdot 2 \mathrm{~m} \mathrm{OD}$, which was approximately $2 \mathrm{~m}$ below the original outlet from the lake. To accommodate this lower outlet level, the river bed was regraded into the lake and for a distance of
$3.6 \mathrm{~km}$ downstream. The sluices consist of four counter balanced gates, each $5.2 \mathrm{~m} \times 4.3 \mathrm{~m}$ deep. There are also two $3 \mathrm{~m}$ wide fishlock gates, which assist the passage of migratory fish through the sluices at times when it is not possible for them to pass through the main gates. 
The new sluices theoretically allowed the control of lake levels between levels of 159.2 and $163.5 \mathrm{~m}$ OD providing $18000000 \mathrm{~m}^{3}$ of controllable storage in Bala Lake. This could be operated on a seasonal basis for low-flow regulation to support continuous abstractions totalling $235 \mathrm{Ml} / \mathrm{d}$ by six Statutory Water Undertakings and British Waterways Board. The volume required to support this level of abstraction being calculated at $6364400 \mathrm{~m}^{3}$. In addition, controlled short-term detention of flood run-off from the substantial Bala Lake catchment area greatly reduced the frequency and extent of flooding in the Dee Valley downstream of Bala, and around Bala Lake itself.

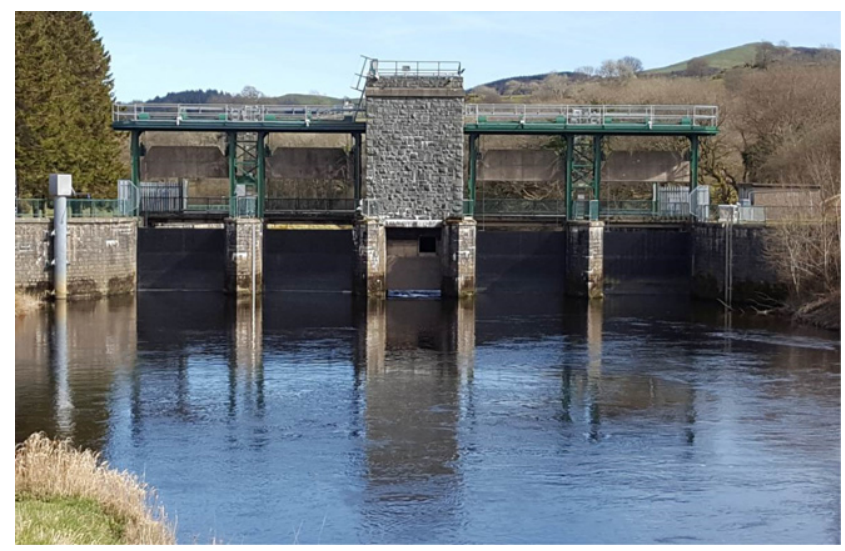

The consulting engineers were Binnie \& Partners and the main contractors Laing Construction.

\subsubsection{River channel modifications}

The scheme included the realignment of the Afon Tryweryn and the cutting of a new outlet channel from Bala Lake. This ensured that discharges from the Tryweryn were also brought under control of the new sluices. Three weirs known as $\mathrm{X}, \mathrm{Y}$ and $\mathrm{Z}$ were constructed as part of the works. Weirs $\mathrm{X}$ and $\mathrm{Y}$ serve to reduce the level of the Tryweryn to the level of the new outlet channel, with weir $\mathrm{X}$ measuring the total flow discharging from the Tryweryn catchment. Weir $Z$ is effectively the system spillway. It enables both the Tryweryn and the Dee to bypass the sluices, under high flow conditions, or at extremely high lake levels.

\subsection{Reservoir remedial works}

Following a Section 10 Inspection in 2014, by Andy Hughes of Atkins (Hughes, 2014), the following 'Matters in the Interest of Safety' were recommended:

'Works are carried out to safely accommodate the design storm and associated still water flood surcharge and wave surcharge'.

'A seepage/stability analysis be carried out on the embankment to try to predict how the embankment will behave in the design flood'.

These works are currently being investigated by Black \& Veatch.

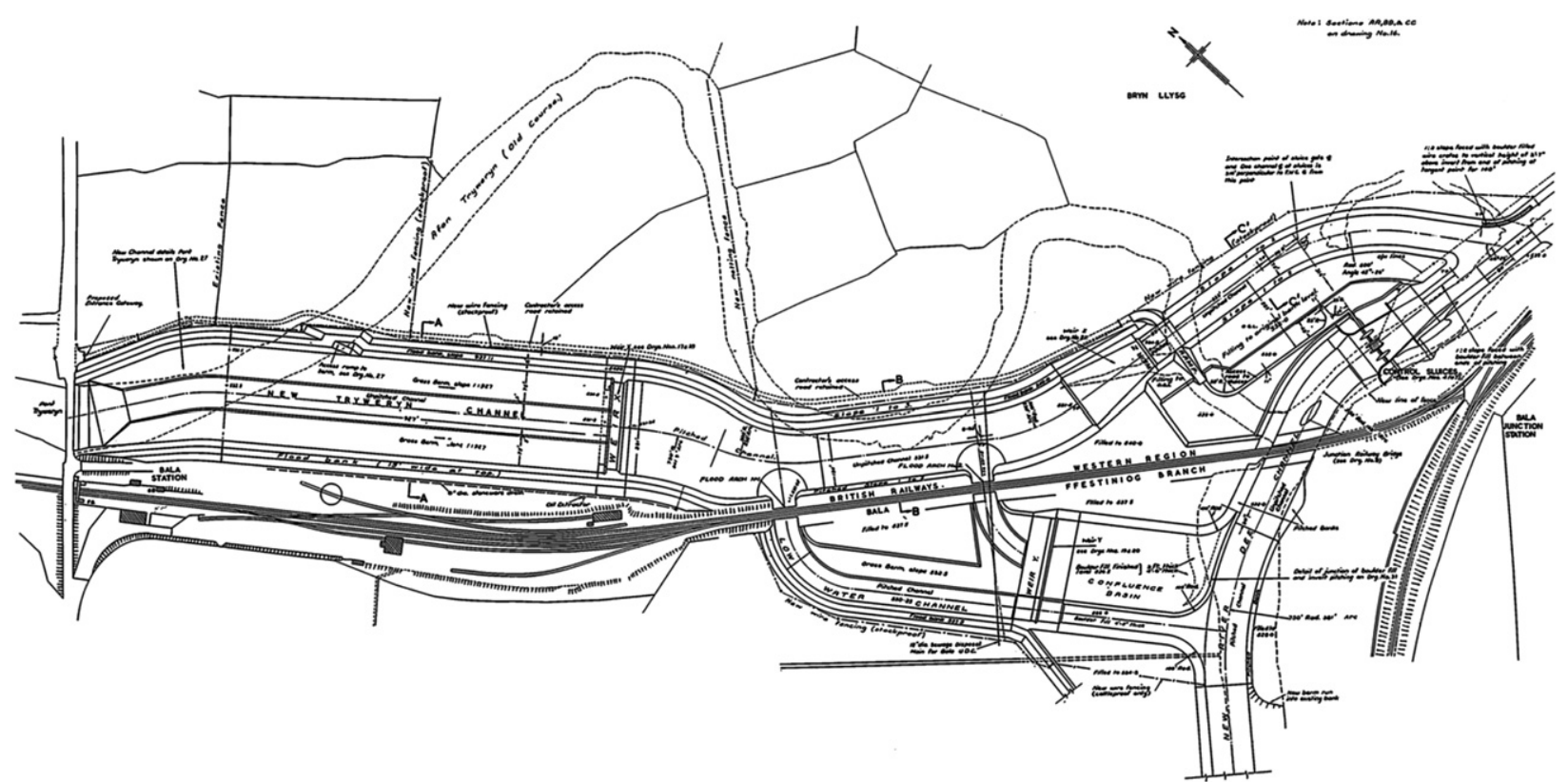

Figure 5. Bala Lake Scheme - Tryweryn Plan 


\section{Llyn Celyn}

\subsection{History}

In 1954 the Water Committee of the Liverpool Corporation reviewed the available resources of its waterworks undertaking and decided that investigations were necessary to identify additional sources of supply and appointed Professor Shackleton for the geological work and Binnie and Partners for the preliminary engineering work. In 1955 the Water Committee received a report from the consultants recommending the Tryweryn Scheme. A bill was deposited in Parliament in 1956 and after much opposition received Royal Assent in August 1957. The Liverpool Corporation Act, 1957, authorised the construction of the Tryweryn reservoir (later renamed Llyn Celyn) to impound the Afon Tryweryn and two adjacent catchwaters. The site of the reservoir is $8 \mathrm{~km}$ upstream of the confluence of the Afon Tryweryn and River Dee at the Bala Sluices. At Huntington, about $3 \mathrm{~km}$ upstream of Chester Weir, the Corporation could abstract from the River Dee up to $295 \mathrm{Ml} / \mathrm{d}$. The Act required compensation discharges of $32 \mathrm{Ml} / \mathrm{d}$ in the 6 months period during October to March and $64 \mathrm{Ml} / \mathrm{d}$ during April to September. Preliminary work started in November 1959, with work on the dam starting in August 1960 and substantial completion in August 1965.

The Corporation has also been empowered by the Liverpool Corporation Act, 1962, to construct works for generating electricity at the dam using the water discharged from the dam.

The main contractors for the civil engineering works were Tarmac Civil Engineering Ltd.

\subsection{Scheme}

The top water level of the reservoir is $297 \cdot 18 \mathrm{~m} \mathrm{OD}$ and the highest point of the catchment is $853 \mathrm{~m}$ OD at Arenig Fawr. The direct catchment of the Afon Tryweryn upstream of the dam, which is mainly moorland, is 6070 ha. Run off from the subsidiary catchment of the Afon Hesgin of 990 ha is led into the reservoir by a piped catchwater. A second catchwater of 850 ha, round the eastern and southern slopes of Arenig Fawr was also authorised, but not constructed.

The dam is near the eastern edge of the highly folded and faulted Middle Ordovician rocks which form the Arenig mountains. It is founded on hard rhyolitic tuffs, which have been glacially eroded, leaving a buried rock bar across the valley. They are overlain by glacial deposits of varying thickness. Deposits of fluvioglacial gravels exist in the reservoir area at Capel Celyn and of glacial clay on the south side of the river downstream of the dam. These deposits were excavated for the construction of the dam.
The works in the Tryweryn Valley are within the Snowdonia National Park so the Corporation was required by the Act of 1957 to have regard for, and enjoyment by, the public of the natural beauty of the area. The construction required the demolition of the chapel, school, post office and 11 inhabited farmhouses and cottages at Capel Celyn.

\subsection{The dam}

The dam consists of an earth embankment, curved to suit the landscape (Crann, 1968). It is constructed of locally won gravels and clay (Figures 6 and 7). The gravel was obtained from the bed of the reservoir and the clay from a borrow-pit in the south side of the valley downstream of the dam. The materials were compacted by vibrating rollers. The gravels form the free-draining upstream and downstream shoulders of the dam and the clay forms the rolled clay core. The rolled clay core is inclined downstream and is founded on the rhyolitic bedrock in which a shallow concrete key has been formed. The surface of the bedrock is about $10 \mathrm{~m}$ below the original ground level at its deepest section, near the centre of the dam. The bedrock was first blanket-grouted with cement to a depth of about $12 \mathrm{~m}$ over its area of contact with the clay core. Beneath the centre line of the concrete key a cement grout curtain extends across the valley to a depth of about 45-60 m.

During construction of the embankment, the river was diverted through a tunnel which now carries the draw-off and scour pipes and is the access to the draw-off tower.

The coffer dam which diverted the river into the tunnel now forms part of the embankment. The upstream face of the embankment is protected by rip rap and is topped by a low wave wall.

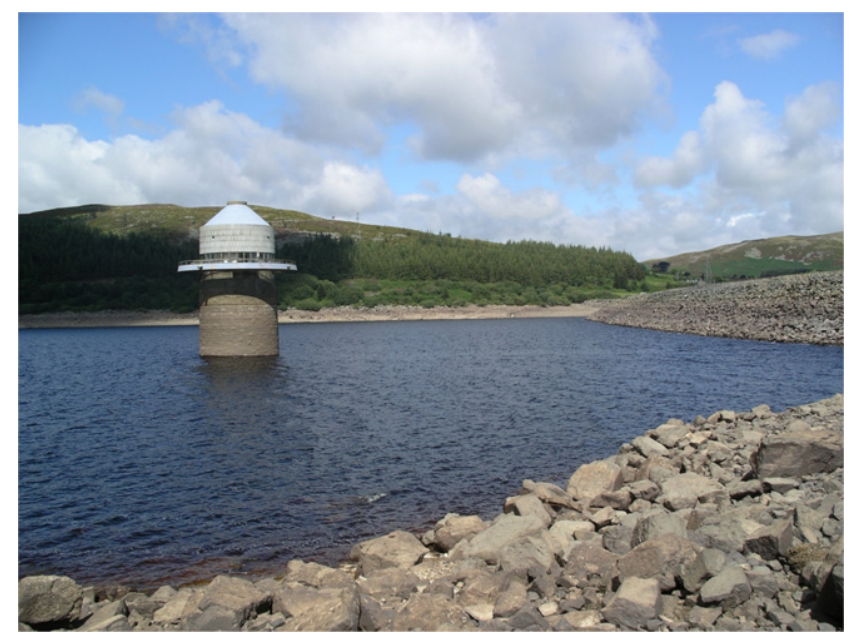

Figure 6. Celyn Dam 


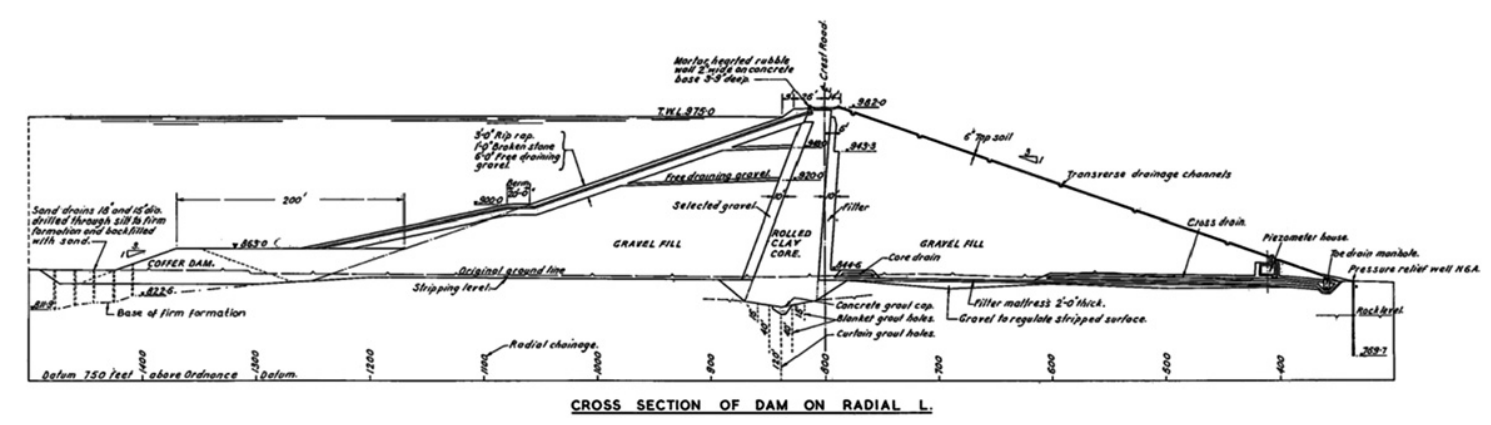

Figure 7. Section through Celyn Dam

\subsection{The outlet works}

The draw-off tunnel of horseshoe cross-section, was excavated partly in tunnel and partly open cut. It has an equivalent diameter of $4.4 \mathrm{~m}$. When impounding began in September 1964 , the tunnel was plugged at its upstream end by concrete $6 \mathrm{~m}$ thick. The tunnel contains the $1.67 \mathrm{~m}$ diameter draw-off pipe to the discharge regulators and the turbines, the $0.91 \mathrm{~m}$ diameter scour pipe from the plug and the equipment for operating both the syphons and the valves, which control the flow through these pipes. It also provides access to the bottom of the draw-off tower where there is a lift and staircase.

The air compressors and vacuum pumps for operating the syphons are located in the power house. The syphons in the draw-off tower can draw-off large quantities of water (up to $1135 \mathrm{Ml} / \mathrm{d}$ ) at any of the five different levels without the need for large diameter valves and pipework. The flow through the tower can be shut off by breaking the syphons with compressed air and by lowering a bulkhead roller gate in the wet well and by closing the self-closing valve in the draw-off pipe at the base of the tower. Daily regulation of the outflow is by discharge regulators operating in discharge tubes at the foot of the embankment or by the control valves of the hydro-electric plant, all discharging into the stilling basin.

The bellmouth spillway is $24.4 \mathrm{~m}$ diameter and designed for a maximum discharge of $310 \mathrm{~m}^{3} / \mathrm{s}$. It is encircled by a boat fender. The spillway and boat fender are accessible from the southern shore by a pre-stressed concrete footbridge. The overflow tunnel is the same size as the draw-off tunnel and discharges into the same stilling basin.

The power house contains three Francis turbines of 2.8, 1.1 and $0.4 \mathrm{MW}$ capacity and one Turgo-type turbine of $0 \cdot 1 \mathrm{MW}$ capacity.

Some water in the reservoir is held in reserve to make special releases down the river for a number of purposes. These include, protection of fisheries and other features of the SAC, reducing the impact of adverse water quality on the environment and on the potable abstractions, hydropower and specific white water events for international level white water canoeing, and rafting at the Canolfan Tryweryn National White Water Centre.

\section{Llyn Brenig}

\subsection{History}

At the end of the nineteenth century, the Corporation of Birkenhead asked Dr G. F. Deacon to investigate supplies, which could replace the inadequate and increasingly polluted well, which were restricting the expansion of their city. Dr Deacon proposed a gravity supply piped from mountain catchments in Wales, by staged development of two reservoirs, one on the Afon Alwen and the other on the nearby Afon Brenig. The Birkenhead Water Act 1907 authorised the construction of these reservoirs for the supply of water to Birkenhead and other authorities.

The land for the Brenig scheme was acquired soon after 1907, although various difficulties delayed detailed surveying and investigation until 1948. This led to a report in 1951 which drew attention to the considerable depth of drift overlying rock on the right bank at the dam site but recommended a reservoir with retention level $359 \mathrm{~m}$ OD giving a reliable yield of $30 \mathrm{Ml} / \mathrm{d}$. A year after that report, in 1951, the Dee and Clywd River Board Act empowered the River Board to construct the Bala Lake works. As a participant in the Bala Lake scheme, Birkenhead no longer needed to proceed with the Brenig Reservoir.

The Dee and Clywd River Authority, constituted in 1963, assessed that the future water needs of north-east Wales, Merseyside, south Lancashire, the Wirral and mid-Cheshire could be served by the construction of a third River Dee regulating reservoir in the Brenig valley. A report by consulting engineers Binnie and Partners in 1970 recommended a twostage development of the reservoir, the second stage requiring 
a pumping system to feed the enlarged storage from the River Dee during winter only. An order authorising construction of the works was made in 1972. Construction of the first stage started in July 1973.

\subsection{Scheme}

The first-stage works store water from the direct catchment upstream of the dam and releases of water are made from the reservoir at the dam into the Afon Brenig, a tributary of the River Dee. These releases consisted of continuous flows of the compensation water as required by the Birkenhead Acts for the earlier use of the site and regulating releases as required by the flow in the River Dee at Eccleston Ferry in accordance with agreed operating rules. A first stage reservoir with a capacity of $60000 \mathrm{Ml}$ in conjunctive operation allowed the minimum flow at Eccleston Ferry to be raised by $290 \mathrm{Ml} / \mathrm{d}$. (The Dee is no longer regulated at Eccleston Ferry. Flows are maintained at Chester Weir and at Manley Hall.) The first stage work contains provisions for raising the dam by $21 \mathrm{~m}$ without emptying the reservoir and for bringing refill water through the outlet works under the dam to the reservoir. This

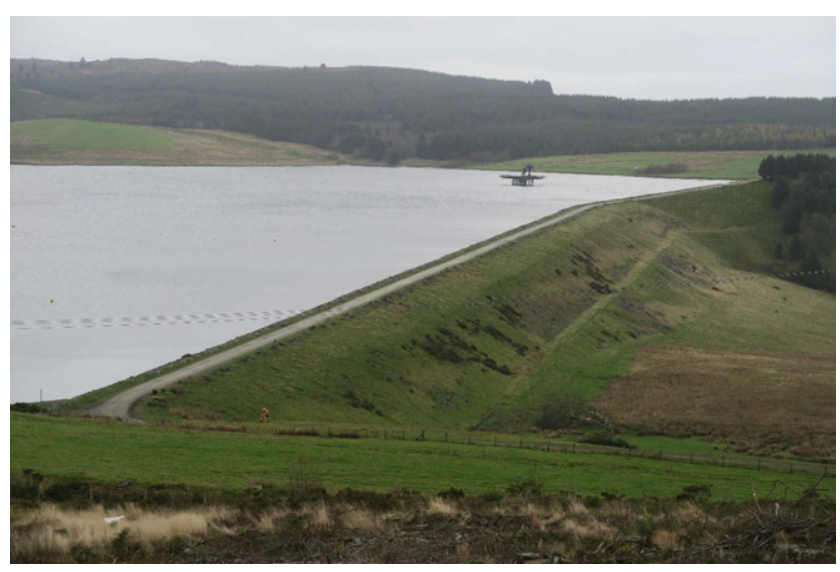

Figure 8. Brenig Dam would provide storage of $170000 \mathrm{Ml}$ with a yield of a further $270 \mathrm{Ml} / \mathrm{d}$.

\subsection{The dam}

The dam is built with quarried Silurian mudstone shoulders supporting a sloping core of Boulder Clay glacial drift and is founded partly on the mudstone rock and partly on drift (Figures 8 and 9). The Brenig Valley is partially blocked by two large drumlins (rounded oval hills formed by glacial action on unconsolidated sediments) overlying Silurian mudstone and drift clays. The dam constructed to create Llyn Brenig was sited to exploit the natural advantage of the topography, and incorporated the drumlins into its structure, reducing the quantity of material required. The downstream (south) face has a gradient that varies from 1 in 1.5 near the crest to 1 in 4 at the toe, while the upstream face slopes at 1 in 2 . Both faces include a pair of berms, giving them a stepped appearance.

The dam's core of rolled boulder clay is laid to a slope of 1 in $1 \cdot 25$, and is inclined upwards towards the downstream face. This reduces the risk of the core developing tensile stresses from differential settlement. Its horizontal thickness is about $10 \mathrm{~m}$ at the crest and some $14 \mathrm{~m}$ at the toe. The clay is sandwiched between protective sand and gravel filters. A grout curtain forms a cut-off from the base of the core down into the bed rock below.

The dam is $1.2 \mathrm{~km}$ long, with a crest level $380 \mathrm{~m}$ above sea level. The top water level is $3 \mathrm{~m}$ lower, and the maximum height to the spillway is $47 \mathrm{~m}$. The dam was completed in June 1976. The reservoir is up to $45 \mathrm{~m}$ deep and covers an area of $372 \mathrm{ha}$. It has a maximum capacity of $61525000 \mathrm{~m}^{3}$.

\subsection{The outlet works}

A draw off tower is located just north of the dam, on the east side of the lake on the line of the Afon Brenig. It is a reinforced concrete structure $55 \mathrm{~m}$ high, rectangular in plan and divided into four shafts. The shafts contain the spillway,

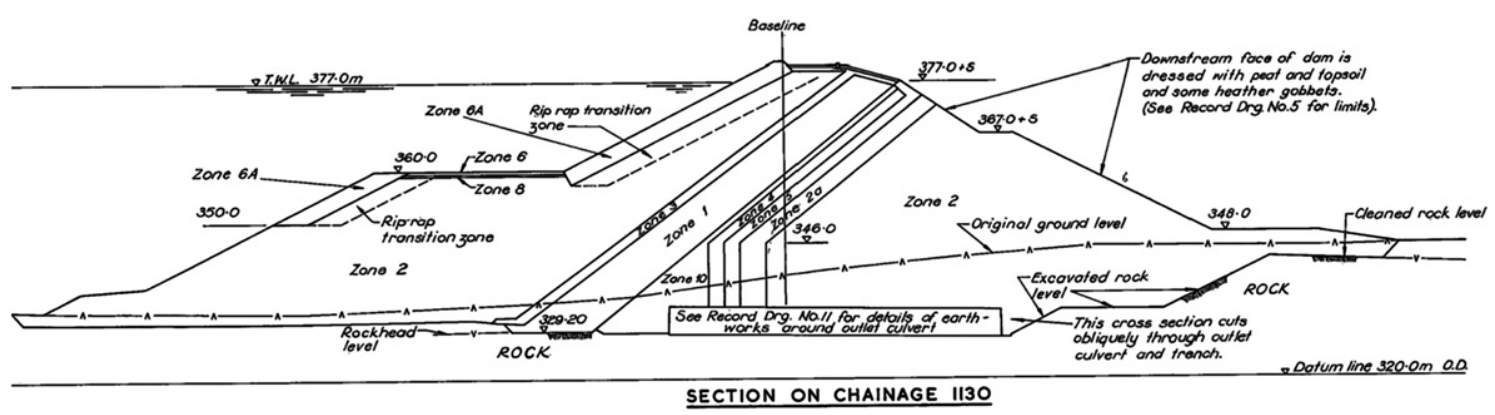

Figure 9. Section through Brenig Dam 


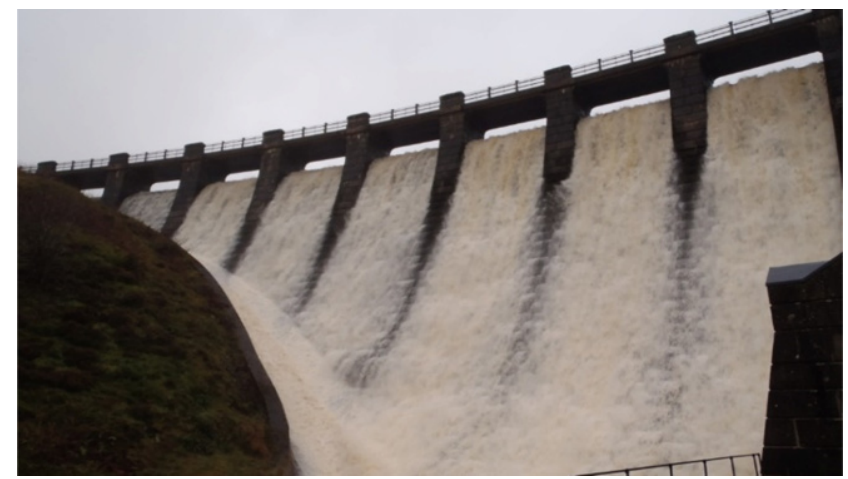

Figure 10. Alwen Dam

the draw-off standpipe, the dry stairwell and access to the scour gate. A $10 \mathrm{t}$ crane for handling equipment is installed on top of the tower.

The culvert running between the dam from the tower to the control structure is a reinforced concrete twin-box culvert $320 \mathrm{~m}$ long. The eastern box contains the spillway and the dry western box the outlet pipework and access to the tower.

The control structure at the toe of the dam contains the stilling basin for the spillway shute and the pipework, valves and stilling basin for the regulation and compensation releases. Above is the administration block.

A major upgrade of the MEICA works associated with the scour and emergency drawdown works are due to take place during 2018/2019.

\section{Alwen reservoir}

Work first stated in 1909, but water only reached Birkenhead in 1921 due to delays caused by the First World War. In 1974 the ownership was transferred to Welsh Water. By the early 1980 s, $50 \%$ of the water was being supplied to north-east Wales. This became $100 \%$ in 1986 .

The dam consists of two parts; the principle section consists of a gravity dam constructed in mass concrete faced with concrete blocks, and a subsidiary earthen embankment extending into the hillside. The dam is $27 \mathrm{~m}$ high and stores $14240 \mathrm{Ml}$ of water (Figure 10). There are two draw-offs for supply in a valve shaft inside the main dam. A third draw-off at the bottom of the dam is for scour and emergency draw down purposes and provides by way of a small turbine, which powers the treatment works, compensation water to the Afon Alwen. When full the water level in the reservoir is $362.71 \mathrm{~m}$ OD and originally providing sufficient pressure to transfer around $40 \mathrm{Ml} / \mathrm{d}$ along the aqueduct by gravity. The engineer was Sir Alexander Binnie, Son and Deacon, and the contractor was Sir Robert McAlpine.

\section{Acknowledgements}

This paper is based on information from National Resources Wales, Dwr Cymru Welsh Water and Black \& Veatch, and their predecessor organisations. The author acknowledges the support from these organisations and their staff in developing the paper.

\section{REFERENCES}

Hughes AK (2014) Statutory Inspection Report Llyn Tegid-Reservoirs Act 1975. Atkins Water, Epsom, UK.

Crann HH (1968) The design and construction of Llyn Celyn. Journal Institution Water Engineers 22(1): 13-71.

\section{How can you contribute?}

To discuss this paper, please email up to 500 words to the editor at editor@britishdams.org. Your contribution will be forwarded to the author(s) for a reply and, if considered appropriate by the editorial board, it will be published as discussion in a future issue of the journal. 